\title{
Anti-Inflammmatiry Effects of Nerium indicum Ethanol Extracts through Suppression of NF-kappaB Activation
}

\author{
Tae-Hwan Kim', Seog Soon Ko ${ }^{3}$, Cheol Park ${ }^{6}$, Sang-Eun Park', Sang-Hoon Hong', \\ Byung Woo Kim ${ }^{4,5,6}$ and Yung Hyun Choi ${ }^{24,6 *}$
}

Departments of ${ }^{1}$ Internal Oriental Medicine and ${ }^{2}$ Biochemistry, and Research Institute of Oriental Medicine, Dongeui University College at Oriental Medicine, 614-052, Korea, ${ }^{3}$ Gaya Middle School, Busan 614-013, Korea, " Department of Biomaterial Control, Graduate School, ${ }^{5}$ Department of Life Science and Biotechnology and ${ }^{6}$ Blue-Bio Industry Regional Innovation Center, Dong-Eui University, Busan 614-714, Korea

Received May 30, 2010 / Accepted July 19, 2010

\begin{abstract}
Nerium indicum, an India-Pakistan-originated shrub belonging to the oleander family, is reported to possess many pharmacological activities including cardiac muscle stimulation, and anti-diabetes, anti-angiogenesis, anti-cancer and neuro-protective activities. However, the anti-inflammatory properties of $N$. indicum were unclear. In this study, we investigated the effects of ethanol extract of the $N$. indicum leaf and stem (ENIL and ENIS) on the expression of anti-inflammatory mediators in U937 human pre-monocytic cell models. In U937 cells stimulated with phorbol 12-myristate-13-acetate (PMA), pre-treatment with ENIS significantly inhibited the expression of both cyclooxygenase-2 (COX-2) mRNA and protein, which are associated with inhibition of the release of prostaglandin $\mathrm{E}_{2}\left(\mathrm{PGE}_{2}\right)$, whereas the inhibitory effects appeared weakly in ENIL. Moreover, ENIS significantly attenuated

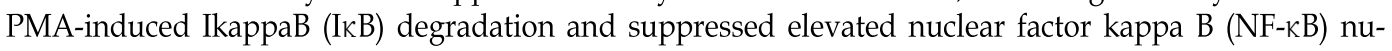
clear translocation. Taken together, these findings provide important new insights that $N$. indicum exhibits anti-inflammatory properties by suppressing the transcription of pro-inflammatory cytokine genes through the NF-kB signaling pathway.
\end{abstract}

Key words : Nerium indicum, cyclooxygenase-2, prostaglandin $\mathrm{E}_{2}$, nuclear factor-kappaB

\section{서 론}

염증은 외부자극에 의하여 유발되는 상처에 대한 생체조직 방어반응의 하나로써 혈류량 및 체온의 증가, 홍조 현상, 종창 및 통증을 동반하는 것으로 알려져 있다[15,30]. 염증 반응은 상처 치유와 같은 생리적 과정을 조절하는데 있어서도 중요하 지만 류마티스 관절염, 알츠하이머병과 같은 신경성 질환을 포함하는 여러 가지 만성적 질환의 중요한 원인으로 작용한다 [38]. 이러한 염증반응에 있어서 중요한 역할을 하는 prostaglandins (PGs)는 염증뿐 만 아니라 세포 분열이나 증식을 조 절함으로서 각종 인체 질병과도 밀접한 연관이 있는 것으로 밝혀지고 있다. PGs의 합성은 cytosolic phospholipases A2 (cPLA2) 및 여러 종류의 secretory PLA2s (sPLA2) 등과 같은 PLA2s에 의하여 phospholipid membrane으로부터 arachidonic acid (AA)가 방출되면 cyclooxygenases (COXs)에 의하 여 $\mathrm{PGH}_{2}$ 로 전환이 되고 마지막으로 specific한 $\mathrm{PG}$ 합성효소에 의해 $\mathrm{PGH}_{2}$ 가 각각의 $\mathrm{PG}$ 로 전환이 됨으로서 종결된다[27,34]. 특히 여러 종류의 $\mathrm{PGs}$ 중 $\mathrm{PGE}_{2}$ 는 $\mathrm{PGE}$ synthase (PGES)에 의하여 유발되어 염증 과정에 있어서 중요한 역할을 하는 것

*Corresponding author Tel : +82-51-850-8649, Fax : +82-51-853-4036 E-mail : choiyh@deu.ac.kr
으로 알려져 있다[25,36]. PGs의 합성에는 2가지의 COX isoform이 관여하고 있는데, COX-1의 경우에는 대부분의 조직에 서 일정한 수준으로 발현되어 혈소판 활성화, 위장의 보호 등 과 같은 인체의 항상성 유지에 관여하는 반면, $\mathrm{COX}-2$ 의 경우 는 cytokine, ultraviolet $(\mathrm{UV})$, 세균성 endotoxin 및 tumor necrosis factor 등과 같은 여러 종류의 pro-inflammatory agent 에 의하여 유발되어 염증뿐 만 아니라 각종 퇴행성 질환의 발병과 진행에 중요한 역할을 한다[3,39]. 특히 COX-2의 경우 에는 정상세포에 비하여 여러 종류의 암세포에서 높은 수준으 로 발현되고 있으며, COX-2의 과발현에 의하여 암조직에서의 혈관신생 및 전이능이 높아지고 apoptosis에 대한 저항성을 가지는 점으로 보아 특히 염증반응과 함께 세포의 암화에 있 어서도 COX-2가 밀접한 관계를 가진다고 볼 수 있다[4,11,19].

질환, 심혈관 질환, 당뇨, 암 등과 관련된 유전자의 promoter 영역에 결합하여 그들의 유전자 발현을 유도하는 전사 조절인자인 nuclear factor kappa B (NF- $\kappa \mathrm{B})$ 는 염증 반응에 있어서도 중요한 역할을 한다[16,28]. NF- $\mathrm{kB}$ 는 phorbol 12myristate-13-acetate (PMA), cytokine 및 lipopolysaccharide (LPS) 등과 같은 pro-inflammatory stimuli에 노출되면 inhibitor of NFkB (IKB) serine 잔기의 인산화에 의하여 빠르게 활성화되어 핵 안으로 이동됨으로서 COX-2와 같은 염증반응 에 관여하는 유전자들의 transcriptional activator로 작용하는 
것으로 알려져 있다[5,6,24]. 따라서 NF-kB가 염증 유발에 있 어서 중요한 역할을 하는 것으로 밝혀짐에 따라 최근 연구방 향은 전사활성요소와 연관된 상위신호전달경로에 많은 관심 이 모아지고 있으며 이들의 활성을 조절할 수 있는 물질의 탐색작업에 많은 연구가 이루어지고 있다.

협죽도(Nerium indicum)는 용담목(Gentianales), 협죽도과 (Apocynaceae), 협죽도속(Nerium)에 속하며 흰색 및 분홍색 꽃을 가지는 상록 활엽 관목으로서 인도가 원산지이고 주로 중국 및 동남아시아에 분포한다[14]. 가는 타원형 잎은 대나무 잎을 닮았고 꽃은 복숭아꽃을 닮았다하여 '협죽도'라는 이름 이 붙여졌으며 독성분이 다량 함유되어 있으나 중국 전통의학 에서는 진통제 및 강심제로서의 효과가 있는 것으로 알려져 있으며, 파키스탄에서는 제 2 형 당뇨병 치료를 위한 민간요법 으로 사용되고 있다[7]. 최근 연구에 따르면 협죽도에는 여러 종류의 cardiac glycoside, alkaloid 및 carbohydrate가 함유되 어 있어 심근의 활성화, 신생혈관형성 억제, 항암효과 및 신경 세포 보호 작용 등과 같은 약리학적인 효과를 가지는 것으로 보고되고 있다 $[8,13,23,40]$. 또한 협죽도의 잎에서 분리된 arabinogalactan은 mitogen에 의해 유도된 $\mathrm{T}$ 및 B 림프구의 증식을 자극하며, 꽃에서 분리된 rhamnogalacturonan 및 xyloglucan 은 PC12 세포의 증식 및 분화를 유도하는 것으로 보고된 바 있다[7,8]. 이러한 선행연구의 예들에서 협죽도가 다양한 질병 예방과 치료에 효과적일 것으로 추정되지만 현재까지 염증 억 제와 관련된 생화학적 기전에 대한 연구는 미비한 실정이다.

따라서 본 연구에서는 협죽도의 항염증 효과 및 그에 따른 생화학적 기전의 해석을 위하여 협죽도 잎의 에탄올 추출물 (ethanol extract of $N$. indicum leaf, ENIL)과 줄기의 에탄올 추출물(ethanol extract of $N$. indicum stem, ENIS)이 인체혈구 세포인 U937 세포에서 PMA에 의하여 인위적으로 유발된 $\mathrm{COX}-2$ 발현 및 $\mathrm{PGE}_{2}$ 의 생성과 연관된 전사조절인자인 NF-kB 의 활성에 어떠한 변화가 유발되는지를 조사하여 유의적인 결과를 얻었기에 이를 보고하는 바이다.

\section{재료 및 방법}

\section{실험재료}

본 실험에 사용된 협죽도는 부산시 영도구에서 채집된 것을
동정하여 사용하였다. ENIL 및 ENIS를 얻기 위하여 채집된 협죽도의 잎과 줄기를 각각 분리하여 흐르는 물로 충분히 세 척하고 건조시킨 후 잘게 분쇄하였다. 건조된 협죽도의 잎과 줄기 $100 \mathrm{~g}$ 에 ethanol 1 를 첨가하여 $60^{\circ} \mathrm{C}, 150 \mathrm{rpm}$ 으로 3일간 교반 후 상층액만 분리하여 Whatman 필터(No. 2)로 걸러내고 감압 농축과정을 통하여 고형성분을 얻어내어 막자 사발로 잘게 마쇄하고 밀봉시켜 $-70^{\circ} \mathrm{C}$ 초저온 냉동고에 보관하였으 며, 실험 시에는 dimethyl sulfoxide (DMSO)를 이용하여 10 $\mathrm{mg} / \mathrm{ml}$ 의 농도로 만든 다음 이를 적정 농도로 배지에 희석하 여 처리하였다. mRNA 분석을 위하여 사용된 primer는 Bioneer (Taejeon, Korea)에서 구입하였으며(Table 1), 단백질 분석을 위하여 사용된 actin, COX-1, COX-2, NF-kB 및 IkB 항체는 Santa Cruz Biotechnology Inc. (Santa Cruz, CA, USA) 에서 구입하였다. Immunoblotting을 위해 2차 항체로 사용된 peroxidase-labeled donkey anti-rabbit 및 peroxidase-labeled sheep anti-mouse immunoglobulin은 Amersham Life Science Corp. (Arlington Heights, IL, USA)에서 구입하였다.

\section{세포배양}

실험에 사용된 인체혈구세포인 U937 세포는 한국생명공학 연구소에서 분주 받았으며, $10 \%$ fetal bovine serum (FBS)에 $1 \%$ 의 penicillin 및 streptomycin (Biofluids, Rockville, MD, USA)이 포함된 RPMI-1640 배지(Gibco BRL, Grand Island, $\mathrm{NY}, \mathrm{USA}$ )를 사용하여 $37^{\circ} \mathrm{C}$ 및 $5 \% \mathrm{CO}_{2}$ 조건 하에서 배양하였다.

\section{Hemocytometer를 이용한 세포 생존율의 측정}

세포 배양용 6 well plate에 U937 세포를 $1 \times 10^{5}$ 개/ $\mathrm{ml}$ 의 개 수로 well 당 $2 \mathrm{ml}$ 씩 분주한 다음 $\mathrm{ENIL}$ 및 ENIS를 적정농도로 처리하여 배양하였다. 시료 처리 6시간 후 상층액을 제거하고 세포만 남긴 다음 $\mathrm{PBS}$ 를 $1 \mathrm{ml}$ 첨가하여 잘 섞은 후 세포 부유 액과 $0.5 \%$ trypan blue (Gibco BRL)를 동량으로 넣어 2분간 처리하고 도립 현미경(Carl Zeiss, Germany)을 이용하여 살아 있는 세포를 계수하였다. 이에 따른 결과를 Microsoft EXCEL program을 사용하여 분석하였다.

MTT assay에 의한 세포 증식 변화 여부 조사

U937 세포에 ENIL 및 ENIS를 적정농도로 처리하고 6시간

Table 1. Sequence of primers used for RT-PCR

\begin{tabular}{ccc}
\hline Gene name & & \multicolumn{1}{c}{ Sequence } \\
\hline \multirow{2}{*}{ GAPDH } & Sense & $5^{\prime}$-CGG-AGT-CAA-CGG-ATT-TGG-TCG-TAT-3' \\
& Antisense & $5^{\prime}$-AGC-CTT-CTC-CAT-GGT-GGT-GAA-GAC-3' \\
\hline \multirow{2}{*}{ COX-1 } & Sense & $5^{\prime}$-TGC-CCA-GCT-CCT-GGC-CCG-CCG-CTT-3' \\
& Antisense & $5^{\prime}$-GTG-CAT-CAA-CAC-AGG-CGC-CTC-TTC-3' \\
\hline \multirow{2}{*}{ COX-2 } & Sense & $5^{\prime}$-TTC-AAA-TGA-GAT-TGT-GGG-AAA-AT-3' \\
& Antisense & $5^{\prime}$-AGA-TCA-TCT-CTG-CCT-GAG-TAT-CTT-3' \\
\hline
\end{tabular}


동안 배양한 후 배지를 제거하고 tetrazolium bromide salt (MTT, Sigma Chemical Co., St. Louis, MO, USA)를 0.5 $\mathrm{mg} / \mathrm{ml}$ 농도로 희석하여 $200 \mu \mathrm{ll}$ 씩 분주하고 3시간 동안 다시 배양하였다. 배양이 끝난 다음 MTT 시약을 제거하고 DMSO 를 $1 \mathrm{ml}$ 씩 분주하여 well에 생성된 formazin을 모두 녹인 후 96 well plate에 200 씨씩 옮겨서 ELISA reader (Molecular Devices, Sunnyvale, CA, USA)로 $540 \mathrm{~nm}$ 에서 흡광도를 측정 하였다. 측정은 모두 세 번을 하였으며, 그에 대한 평균값과 표준 오차를 Microsoft EXCEL program을 사용하여 분석하였다.

\section{세포의 형태 변화 관찰}

다양한 실험 조건에서 세포의 전체적 형태 변화 여부를 조 사하기 위하여 도립 현미경(inverted microscope, Carl Zeiss) 을 이용하여 200 배의 배율로 관찰하였다. 또한 동일한 조건에 서의 핵의 형태적 변화를 관찰하기 위하여 $37 \%$ formaldehyde 용액과 PBS를 1:9의 비율로 섞은 fixing solution을 모아진 세 포에 첨가하여 상온에서 10 분 동안 고정하였다. 고정된 세포 를 PBS에 부유시킨 후 cytospin을 이용하여 slide glass 위에 세포를 부착시키고 4',6-diamidino-2-phenylindole (DAPI, Sigma) 용액을 처리하여 염색하였다. 형광 현미경을 이용하여 400 배의 배율로 세포의 핵의 형태 변화를 관찰하였다.

\section{Western blot analysis에 의한 단백질 발현의 분석}

다양한 조건에서 준비된 세포들을 모은 다음 적당량의 lysis buffer [25 mM Tris-Cl (pH 7.5), $250 \mathrm{mM} \mathrm{NaCl}, 5$ mM EDTA, $1 \%$ NP-40, $1 \mathrm{mM}$ phenymethylsulfonyl fluoride (PMSF), 5 $\mathrm{mM}$ dithiothreitol (DTT)]를 첨가하여 $4^{\circ} \mathrm{C}$ 에서 1 시간 동안 반 응시킨 후, $14,000 \mathrm{rpm}$ 으로 30 분간 원심분리하여 그 상층액을 취하였다. 상층액의 단백질 농도는 Bio-Rad 단백질 정량 시약 (Bio-Rad, Hercules, CA, USA) 사용방법에 따라 정량 한 다음 동량의 Laemmli sample buffer (Bio-Rad)를 섞어서 sample을 만들었다. 이렇게 만든 동량의 단백질을 sodium dodecyl sulphate (SDS)-polyacrylamide gel을 이용하여 전기영동으로 분 리한 다음 nitrocellulose membrane (Schleicher and Schuell, Keene, $\mathrm{NH}, \mathrm{USA}$ )으로 electroblotting에 의해 전이시켰다. 전이 가 끝난 membrane에 1 차 항체를 처리하여 상온에서 2 시간 이상 또는 $4^{\circ} \mathrm{C}$ 에서 over night 시킨 다음 2 차 항체를 사용하여 상온에 서 1 시간 정도 반응시켰다. 반응이 끝난 후 PBS-T $(0.1 \%$ Tween in PBS)로 충분히 세척하고 Enhanced Chemiluminoesence (ECL) 용액(Amersham Life Science Corp.)을 적용시킨 다음 암실에서 X-ray film에 감광시켜 특정단백질의 양을 분석하였다.

\footnotetext{
Rverse transcriptase polymerase chain reaction (RT-PCR)에 의한 mRNA의 분석

준비된 세포를 대상으로 TRIzol reagent (Invitrogen Co., Carlsbad, CA, USA)을 이용하여 total RNA를 분리하고 정량
}

한 다음 primer, DEPC water 그리고 ONE-STEP RT-PCR PreMix Kit (Intron, Korea)를 넣고 Mastercycler gradient (Eppendorf, Hamburg, Germany)를 이용하여 증폭한 다음 $1 \%$ agarose gel을 이용하여 $100 \mathrm{~V}$ 에서 전기영동을 하였다. 전기영동으로 $\mathrm{DNA}$ 분리가 끝난 gel을 ethidium bromide $(\mathrm{EtBr})$ 를 이용하여 염색한 후 UV 하에서 확인하였다. 이때 housekeeping 유전자인 glyceraldehyde-3-phosphate dehydrogenase (GAPDH) 유전자를 internal control로 사용하였다.

\section{$\mathrm{PGE}_{2}$ 의 측정}

$\mathrm{PGE}_{2}$ 생성양의 변화 측정을 위한 $\mathrm{PGE}_{2}$ EIA kit는 Cayman Chemicals (Ann Arbor, MI, USA)에서 구입하였으며, $\mathrm{PGE}_{2}$ 의 양을 측정하기 위하여 정상 및 다양한 농도의 ENIL 및 ENIS를 1시간 선 처리 후 PMA $(40 \mathrm{nM})$ 를 처리한 배지에서 6시간 동안 U937 세포를 배양시킨 다음 상층액만 이용하여 제시된 방법에 따라 처리한 다음 ELISA reader를 이용하여 $420 \mathrm{~nm}$ 의 흡광도를 이용하여 반응의 정도를 측정하였다.

\section{결과 및 고찰}

세포의 생존율 및 증식에 미치는 ENIL 및 ENIS의 영향

ENIL 및 ENIS를 단독 처리했을 경우와 PMA와 동시 처리 했을 경우에 U937세포의 생존율 및 증식에 미치는 영향을 알 아보기 위하여 hemocytometer 및 MTT assay를 이용하였다. Fig. 1A 및 B에서 나타난 바와 같이 ENIL 및 ENIS를 6시간 동안 처리했을 경우 $5 \mu \mathrm{g} / \mathrm{ml}$ 농도까지 큰 변화가 관찰되지 않았다. 다음으로 생존율 및 증식에 큰 영향을 미치지 않는 $5 \mu \mathrm{g} / \mathrm{ml}$ 의 농도로 각각의 시료를 1 시간 선처리한 다음 염증유 발물질로서 $\mathrm{PMA}$ 를 처리하여 6시간 경과 후 변화를 관찰한 결과, Fig. $1 \mathrm{C}$ 및 $\mathrm{D}$ 에 나타난 바와 같이 ENIL 및 ENIS 처리군 모두에서 세포의 생존율 및 증식에 큰 영향을 미치지 못하는 것을 알 수 있었다. 따라서 이후의 실험은 $5 \mu \mathrm{g} / \mathrm{ml}$ 농도의 ENIL 및 ENIS를 사용하여 진행하였다.

\section{세포의 형태에 미치는 ENIL 및 ENIS의 영향}

PMA와 ENIL 및 ENIS 처리에 따른 U937 세포의 전체적인 형태 변화를 알아보기 위하여 ENIL 및 ENIS를 1시간 선처리 후 PMA를 6시간 동안 처리한 다음 $\mathrm{ENIL}$ 및 $\mathrm{ENIS}$ 를 6시간 처리하였을 경우 Fig. $2 \mathrm{~A}$ 에서 보는 바와 같이 세포의 밀도에 큰 변화가 없었으며 전체적인 세포의 형태도 큰 변화가 없음 을 알 수 있었다. 또한 상기와 동일한 조건으로 처리된 U937 세포의 핵의 형태 변화를 조사한 결과에서도 Fig. $2 \mathrm{~B}$ 에서와 같이 염색질 응축에 의한 apoptosis가 일어난 세포에서 전형 적으로 관찰되는 apoptotic body가 관찰되지 않았고 핵의 형 태가 뚜렷하게 정상으로 염색되는 것을 알 수 있었다. 이상의 결과는 $\mathrm{ENIL}$ 및 $\mathrm{ENIS}$ 와 PMA의 단독 또는 복합 처리에 따른 
A)

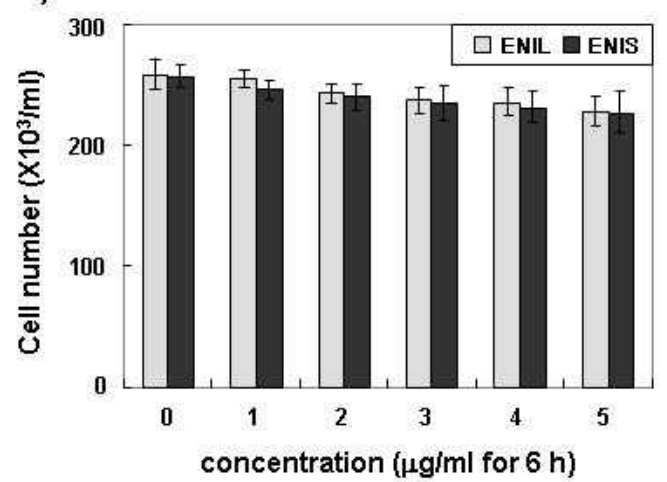

C)

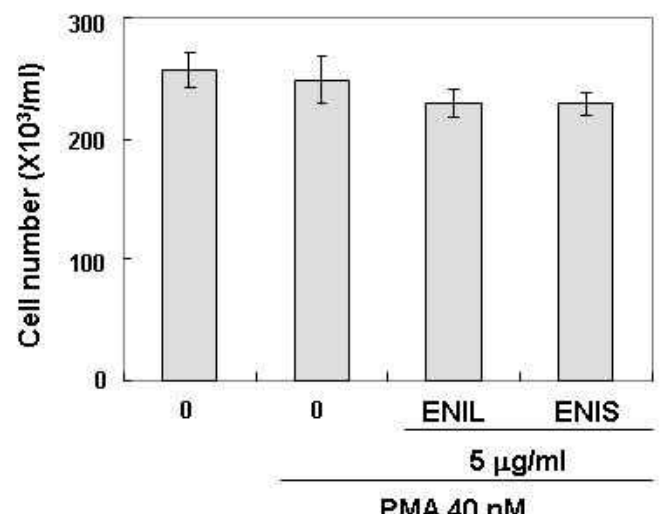

B)

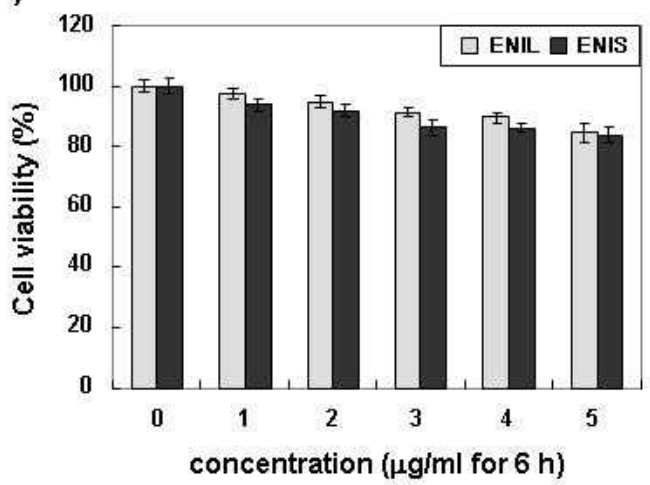

D)

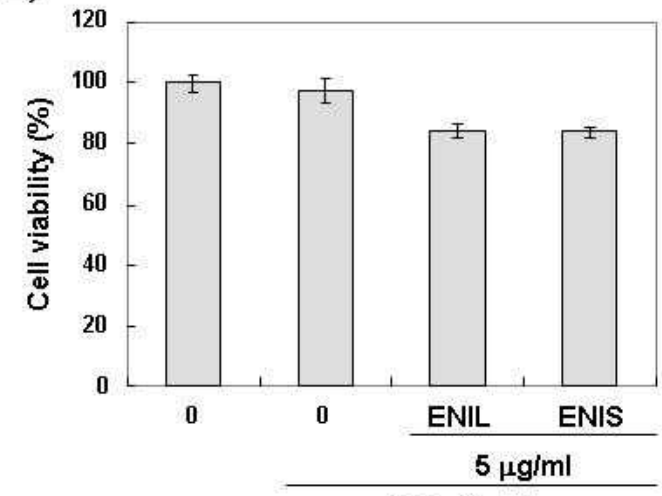

PMA $40 \mathrm{nM}$

Fig. 1. Effects of ENIL, ENIS and PMA on the cell viability and growth of U937 cells. The cells were incubated with the indicated concentrations of ENIL and ENIS (A and B) or $40 \mathrm{nM}$ of PMA for $7 \mathrm{hr}$ after $1 \mathrm{hr}$ pretreatment with $5 \mathrm{\mu g} / \mathrm{ml}$ of ENIL and ENIS (C and D). The rate of cell proliferation was measured by the Hemocytometer and metabolic-bye-based MTT assay. The data shown are means $\pm \mathrm{SD}$ of three independent experiments.

A)
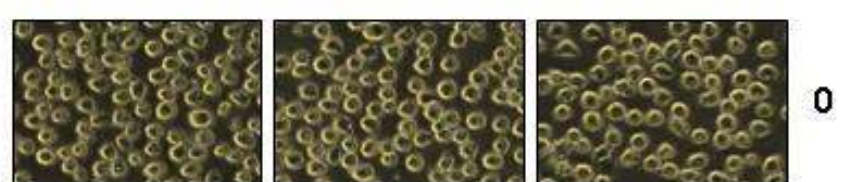

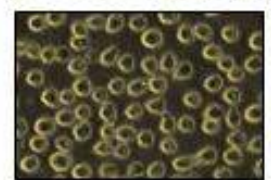

0

B)
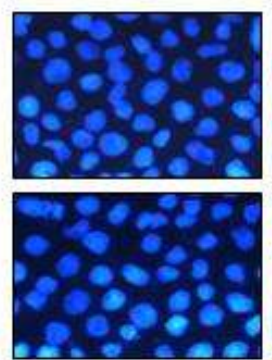

0

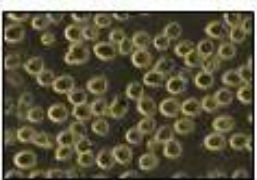

ENIL

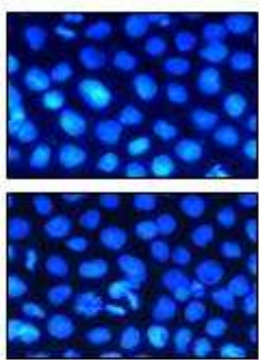

ENIL

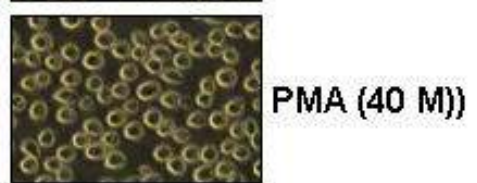

ENIS $(5 \mu \mathrm{g} / \mathrm{ml})$

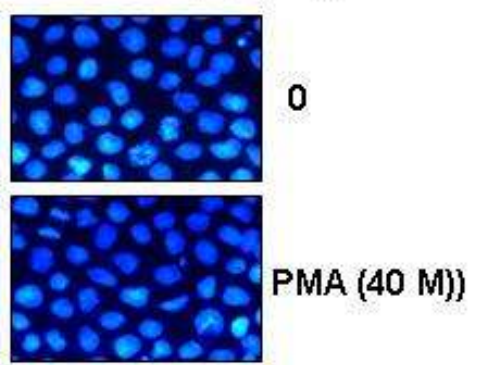

ENIS $(5 \mu \mathrm{g} / \mathrm{ml})$
Fig. 2. Effects of ENIL, ENIS and PMA on cell morphology in U937 cells. The cells were incubated with $40 \mathrm{nM}$ of PMA for $7 \mathrm{hr}$ after $1 \mathrm{hr}$ pretreatment with or without $5 \mu \mathrm{g} / \mathrm{ml}$ of ENIL and ENIS. (A) The cell morphology was visualized by inverted microscope. Magnification, $\times 200$. (B) The cells were stained with DAPI solution. Stained nuclei were then observed under fluorescent microscope using blue filter. Magnification, $\times 400$. 
U937 세포의 생존율 및 증식에 대한 결과와 잘 부합되었다. 즉 이러한 조건은 $\mathrm{ENIL}$ 및 $\mathrm{ENIS}$ 의 단독 처리에 의하여 세포독 성을 나타내지 않음을 의미한다.

\section{$\mathrm{COXs}$ 의 발현에 미치는 PMA의 영향}

$\mathrm{PMA}$ 는 유전자의 전사, 세포의 성장과 분화, apoptosis, 면 역반응 및 protein kinase C signaling pathway를 통한 receptor desensitization 등과 같은 다양한 세포반응을 조절하는 tumor promoter이다[17,26]. 또한 PMA는 강력한 PKC activator로서 성장인자들, 호르몬 및 세포의 성장과 분화를 조절하 는 cytokine에 의한 기전을 연구하는데 사용되며, cytokine 및 LPS와 마찬가지로 여러 세포들에서 COX-2의 발현 및 PGs의 생성을 증가시키는 것으로 알려져 있다 $[18,29,32]$. 따라서 U937 세포에 PMA를 처리하였을 경우 염증 유발에 있어서 중요한 역할을 하는 것으로 알려진 $\mathrm{COX}_{\mathrm{S}}$ 의 발현에 어떠한 영향을 미치는 지를 western blot으로 관찰하였다. 먼저 PMA 의 농도별 처리에 따른 변화를 관찰한 결과, Fig. $3 \mathrm{~A}$ 에 나타난 바와 같이 COX-1의 경우는 아무런 변화가 관찰되지 않았지만 $\mathrm{COX}-2$ 의 경우는 $20 \mathrm{nM}$ 의 농도에서부터 강하게 발현되는 것 을 확인 할 수 있었다. 다음으로 PMA 처리시간에 따른 COX-2 의 발현 정도를 관찰한 결과, Fig. $3 \mathrm{~B}$ 에 나타난 바와 같이 $\mathrm{COX}-2$ 의 경우에는 PMA 처리 1 시간까지는 발현양의 변화가 나타나지 않았지만 2시간째부터 발현양의 증가가 나타나기 시작하여 6시간 처리군에서 현저하게 증가하는 것을 관찰할 수 있었다. 이상의 결과를 살펴볼 때 PMA는 U937 세포의 생 존율 및 증식과 더불어 COX-1의 발현에는 큰 영향을 미치지 못하지만 염증발현에 중요한 역할을 하는 COX-2의 발현을 증가시킨다는 것을 알 수 있었다.

\section{$\mathrm{PMA}$ 에 의한 $\mathrm{COX}-2$ 의 발현 증가에 미치는 ENIL 및 ENIS의 영향}

COX-2는 인체의 정상세포에서는 낮은 수준으로 유지되지 만 여러 종류의 cytokine이나 성장인자에 의해서 증가되면 염 증반응 및 조직의 손상을 유발하는 것으로 알려져 있다 [20,33,35]. 뿐만 아니라 COX-2는 대장암, 전립선암, 유방암 등 을 포함하는 거의 대부분의 암세포에서 과발현되어 있는 것으 로 밝혀지고 있으며, 이러한 COX-2의 과발현 정도가 암환자 의 생존율과 반비례한다고 보고되고 있다[1,2,9]. 본 연구에서 는 PMA에 의해 유발된 COX-2의 과발현 현상이 ENIL 및 ENIS에 의하여 억제될 수 있을지를 확인하기 위하여 각각의 시료를 $5 \mu \mathrm{g} / \mathrm{ml}$ 의 농도로 단독 처리하였을 경우와 1 시간 선처 리한 다음 PMA $40 \mathrm{nM}$ 을 처리하였을 경우에 유발되는 COX-2 의 발현 변화를 전사 및 번역 수준에서 비교하였다. Fig. 4 에서 나타난 바와 같이 COX-1의 경우는 큰 변화가 관찰되지 않았 지만 PMA에 의해서 과발현된 COX-2의 경우에는 ENIS 선처 리에 처리 농도 의존적으로 의해서 전사 및 번역 수준 모두에
A) PMA (nM)

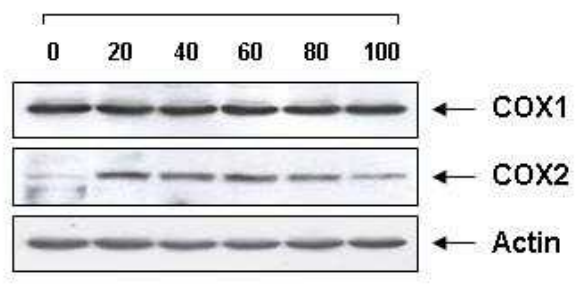

B) Time (h)

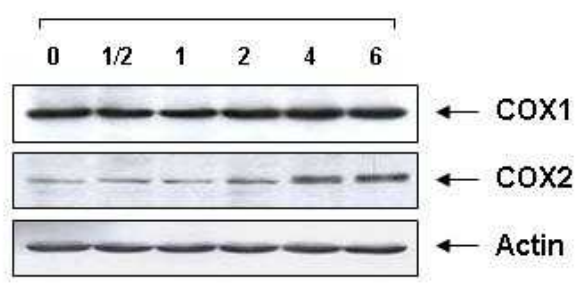

Fig. 3. Effects of PMA treatment on the levels of COXs protein expression in U937 cells. Cells were incubated with various concentrations PMA for $6 \mathrm{hr}$ (A), or incubated with $40 \mathrm{nM}$ PMA for the indicated times (B). The cells were lysed and then cellular proteins were separated by SDS-polyacrylamide gels and transferred onto nitrocellulose membranes. The membranes were probed with the indicated antibodies. Proteins were visualized using an ECL detection system. Actin was used as an internal control.

서 발현의 정도가 현저하게 감소하는 것으로 나타났다. 하지 만 ENIL을 선처리 하였을 경우에는 PMA에 의하여 증가된 $\mathrm{COX}-2$ 의 발현감소 정도가 약하게 나타났다. 즉 염증반응에 중요한 역할을 하는 COX-2의 발현억제 정도에 있어서 ENIL 에 비하여 ENIS의 효과가 더욱 뛰어나다는 것을 알 수 있었다.

\section{$\mathrm{PMA}$ 에 의한 $\mathrm{PGE}_{2}$ 생성 증가에 미치는 $\mathrm{ENIL}$ 및 $\mathrm{ENIS}$ 의 영향 \\ COX-2에 의하여 생성된 $\mathrm{PGE}_{2}$ 는 염증반응에 동반되는 홍} 반, 부종 및 통증 등과 같은 증상의 원인이다[10,12]. 뿐만 아니 라 $\mathrm{PGE}_{2}$ 는 염증성 질환을 포함한 다양한 생체반응에 있어서 도 세포분열이나 증식에 영향을 줌으로서 각종 질병의 유발과 진행에 관여하며, $\mathrm{PMA}$ 는 이러한 $\mathrm{PGE}_{2}$ 의 발현을 증가시키는 것으로 보고되고 있다[21,37]. 따라서 $\mathrm{PGE}_{2}$ 생성에 있어서 ENIL 및 ENIS가 어떠한 영향을 미치는지를 조사한 결과는 Fig. 5에 나타난 바와 같으며, 결과에서 알 수 있듯이 정상 및 ENIL 및 ENIS이 단독 처리된 경우에는 $\mathrm{PGE}_{2}$ 생성에 큰 변화 가 나타나지 않았지만, $\mathrm{PMA}$ 처리에 의한 $\mathrm{PGE}_{2}$ 의 생성 증가는 ENIS 선처리에 의하여 매우 억제됨을 알 수 있었으며, ENIL를 선처리하였을 경우에는 $\mathrm{PGE}_{2}$ 의 억제 현상이 약하게 나타났 다. 이상의 결과를 살펴볼 때 ENIS는 COX-2의 발현억제와 
A)

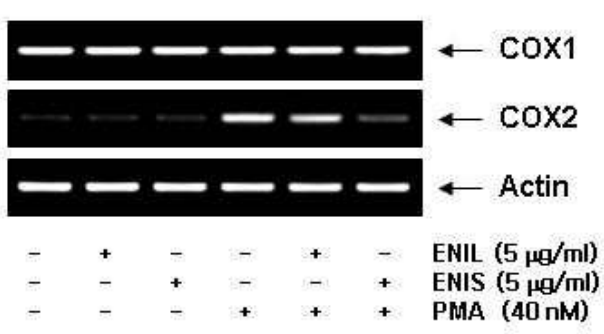

C)

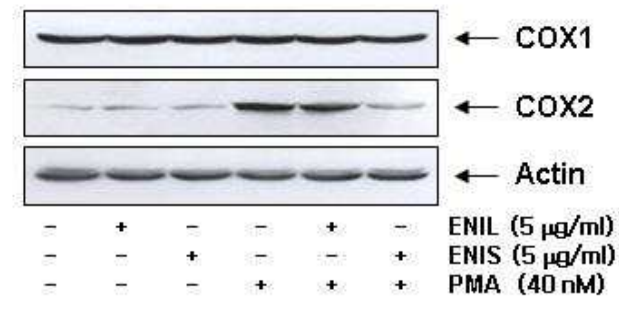

B)

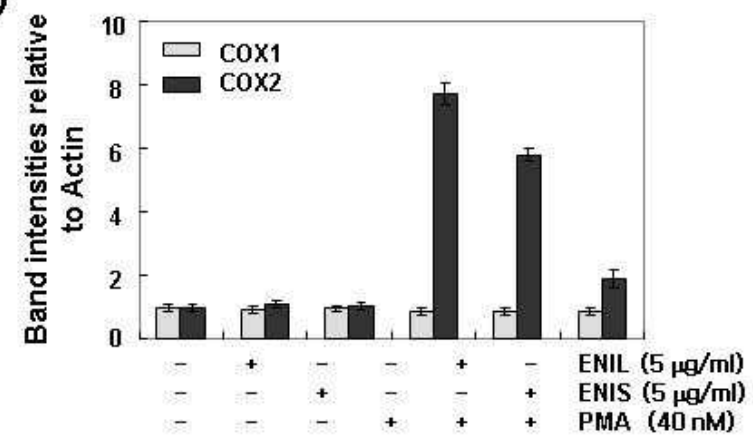

D)

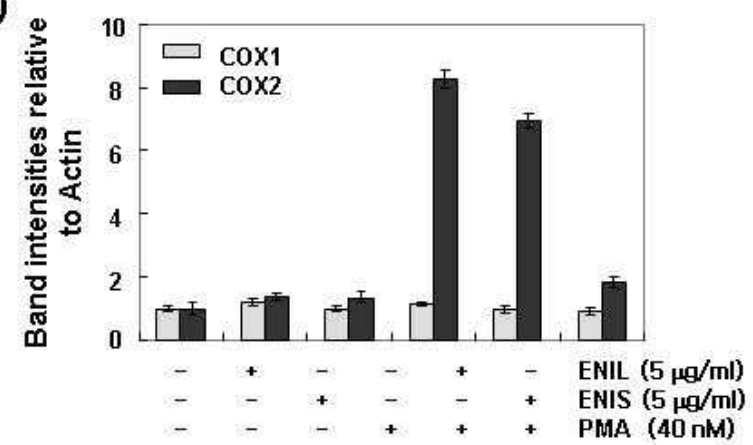

Fig. 4. Effect of ENIL and ENIS on the PMA-induced COX-2 expression in U937 cells. The cells were incubated with $40 \mathrm{nM}$ of PMA for $7 \mathrm{hr}$ after $1 \mathrm{hr}$ pretreatment with or without $5 \mu \mathrm{g} / \mathrm{ml}$ of ENIL and ENIS. (A) Total RNAs were isolated and reverse-transcribed. The resulting CDNAs were subjected to PCR with the indicated primers and the reaction products were subjected to electrophoresis in 1\% agarose gel and visualized by EtBr staining. (C) Cellular proteins were separated by SDS-polyacrylamide gels and transferred onto nitrocellulose membranes. The membranes were probed with the indicated antibodies. Proteins were visualized using an ECL detection system. Actin was used as an internal control. (B and D) The levels of mRNA and protein of COX-1 and COX-2 were normalized by GAPDH and actin, respectively.

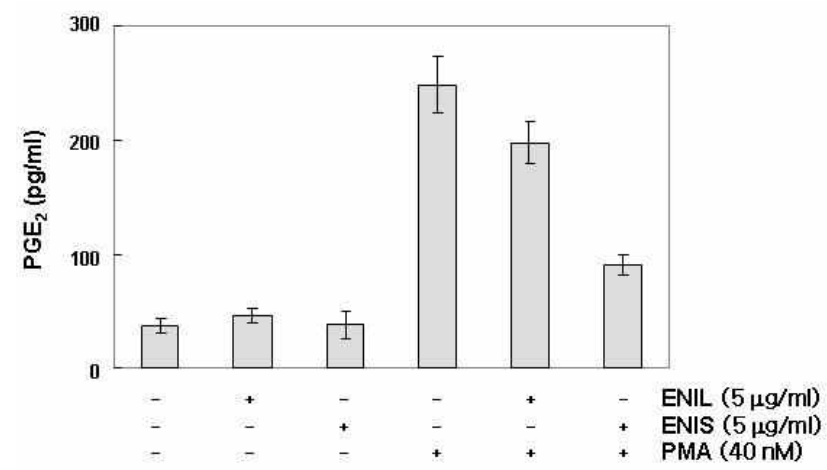

Fig. 5. Effects of ENIL and ENIS on the PMA-induced $\mathrm{PGE}_{2}$ production in U937 cells. The cells were incubated with $40 \mathrm{nM}$ of PMA for $7 \mathrm{hr}$ after $1 \mathrm{hr}$ pretreatment with or without $5 \mu \mathrm{g} / \mathrm{ml}$ of ENIL and ENIS. The PGE 2 accumulation in the medium was determined by an EIA kit as described in materials and methods. The data shown are means $\pm \mathrm{SD}$ of three independent experiments.

이로 인한 $\mathrm{PGE}_{2}$ 의 생성 저해작용이 $\mathrm{ENIL}$ 보다 효과적이었음 을 알 수 있었다.
PMA에 의한 NF-kB 발현 증가에 미치는 ENIL 및 ENIS 의 영향

염증반응에 있어서 NF-kB는 COX-2의 발현을 조절하는 것 으로 알려져 있는데, 일반적으로 NF-kB는 IkB와 결합하여 세 포질에 존재하지만 inflammatory stimuli에 의하여 $\mathrm{IKB}$ 가 degradation되면 자유로워진 NF- $\mathrm{kB}$ 는 핵 내로의 이동이 촉진 되어 전사조절인자로 작용하면서 COX-2의 발현을 증가시킴 으로서 염증반응을 촉진시킨다[22,31]. 따라서 ENIL 및 ENIS 가 NF-kB의 발현에 어떠한 영향을 미치는지를 확인한 결과, Fig. $6 \mathrm{~A}$ 에 나타난 바와 같이 NF-kB의 경우 PMA 처리농도 및 시간 의존적으로 핵 내로의 이동이 증가되었음을 알 수 있었으며, 세포질에서 NF-kB와 결합하고 있는 IkB의 발현은 상대적으로 감소되었다. 다음은 PMA에 의하여 유발된 NF-kB 의 핵 내로의 이동이 ENIL 및 ENIS에 의하여 억제되는지의 여부를 확인한 결과, Fig. 6B에 나타낸 바와 같이 PMA 처리에 의하여 세포질에서 핵 내로의 NF-kB 이동이 ENIS에 의하여 현저하게 억제되었음을 알 수 있었으며, 동시에 세포질에 존 재하는 IKB의 발현도 매우 회복되는 것으로 나타났다. 하지만 $\mathrm{ENIL}$ 처리군에서는 NF-kB의 핵 내 이동 억제의 정도가 ENIS 
A)

C)
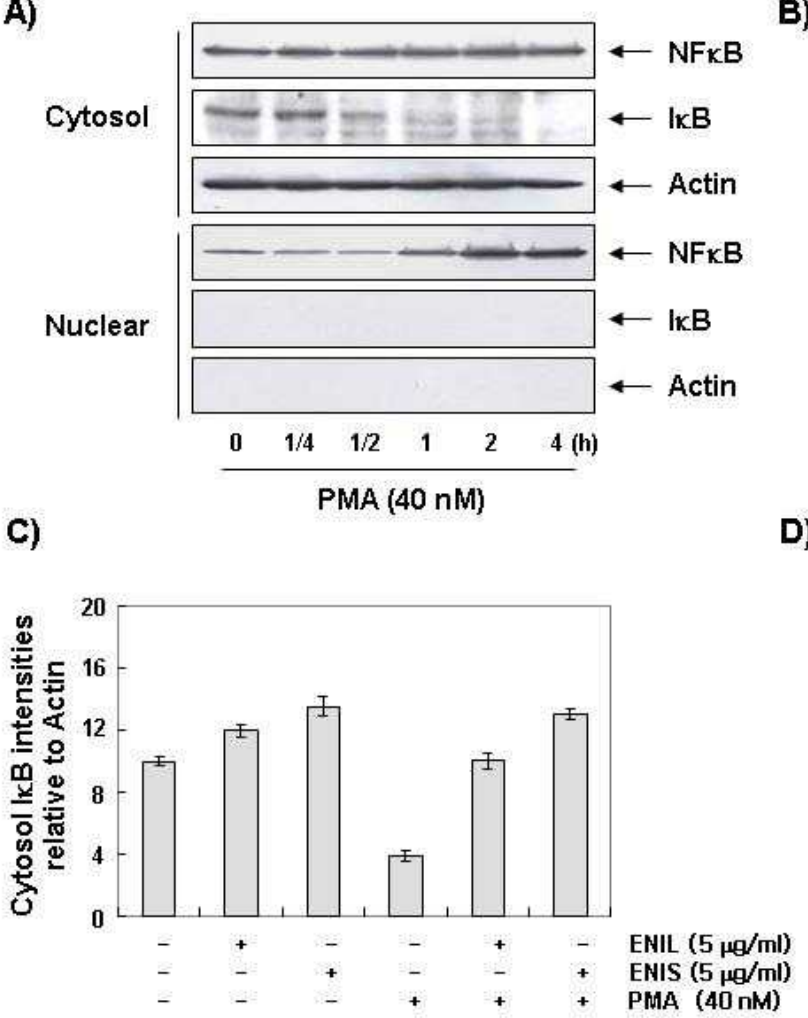

B)

D)
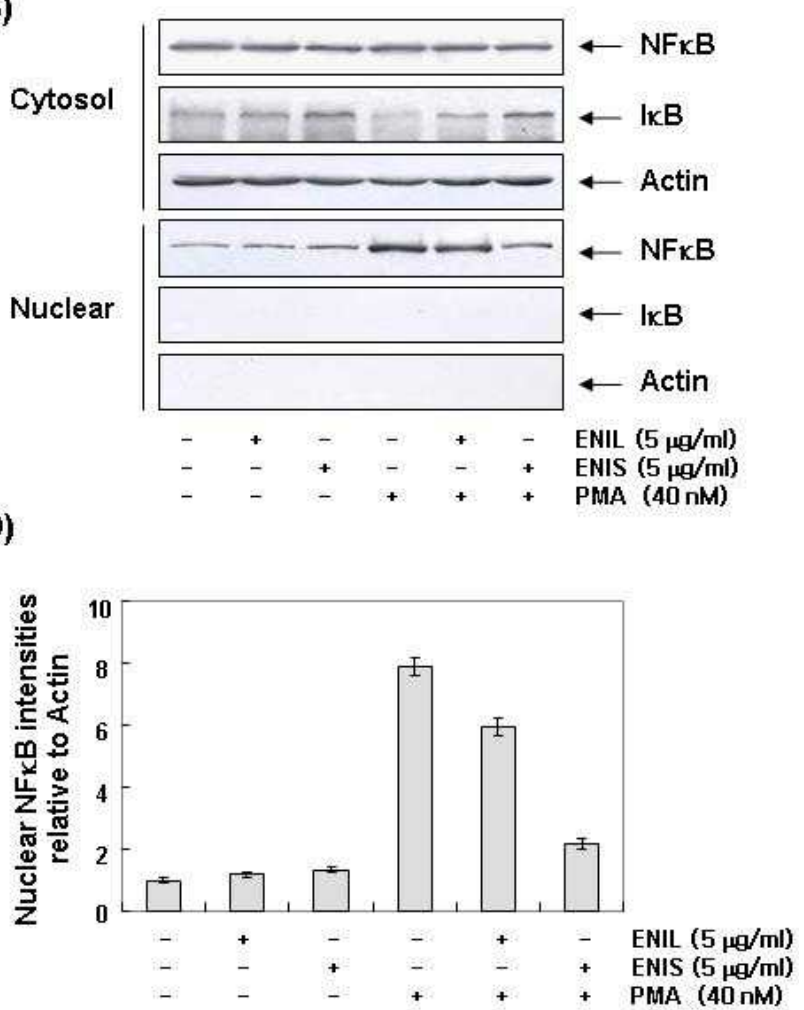

Fig. 6. Effects of ENIL and ENIS on the PMA-induced NF-kB translocation in U937 cells. (A) The cells were treated with $40 \mathrm{nM}$ PMA for indicated times, cytosolic and nuclear proteins were prepared and immunodetected with the indicated antibodies. (B) The cells were incubated with $40 \mathrm{nM}$ of PMA for $3 \mathrm{hr}$ after $1 \mathrm{hr}$ pretreatment with or without $5 \mu \mathrm{gg} / \mathrm{ml}$ of ENIL and ENIS. The cells were lysed and then cellular proteins were separated by SDS-polyacrylamide gels and transferred onto nitrocellulose membranes. The membranes were probed with the indicated antibodies. Proteins were visualized using an ECL detection system. Actin was used as an internal control. (C and D) Protein levels of cytosol I $\mathrm{B}$ and Nuclear NF- $\kappa \mathrm{B}$ were normalized by actin protein.

처리군에 비하여 다소 약한 것으로 나타났다. 결론적으로 협 죽도 추출물은 NF- $\mathrm{kB}$ 의 활성 억제를 통한 COX-2의 발현을 억제함으로서 $\mathrm{PGE}_{2}$ 의 생성을 억제함으로서 항염증 효능을 나 타낸다고 생각된다. 아울러 이러한 협죽도의 항염증 효능에 실질적인 역할을 하는 성분에 대한 추가적인 연구가 진행되어 야 할 것이다.

\section{결 론}

정상세포뿐 만 아니라 형질 전환된 세포의 증식조절에 중요 한 역할을 하는 것으로 알려진 COX-2는 전사조절인자인 NF$\kappa \mathrm{B}$ 에 의해서 조절되며, 염증반응에 있어서 중요한 역할을 하 는 $\mathrm{PGE}_{2}$ 의 생성에 관여하는 것으로 알려져 있다. 본 연구에서 는 U937 인체혈구세포에서 염증유발인자인 PMA에 의해서 유발되는 염증반응에 있어서 중요한 역할을 하는 COX-2 및 COX-2의 산물인 $\mathrm{PGE}_{2}$ 와 COX-2의 발현에 영향을 미치는 전 사조절인자인 NF- $\mathrm{NB}$ 의 발현에 협죽도 잎 및 줄기의 에탄올
추출물인 ENIL 및 ENIS가 어떠한 영향을 미치는 지를 조사하 였다. PMA가 처리된 U937 세포에서 COX-1의 발현에는 아무 런 영향을 미치지 못하였지만 COX-2의 발현 증가가 유도되었 고 이에 따른 $\mathrm{PGE}_{2}$ 의 생성이 증가되었다. $\mathrm{PMA}$ 에 의해서 증가 된 COX-2의 발현이 ENIS 선처리에 의하여 거의 완벽하게 억 제되었고 그에 따른 $\mathrm{PGE}_{2}$ 의 생성도 현저하게 감소되었다. $\mathrm{ENIS}$ 에 의한 $\mathrm{COX}-2$ 의 발현 및 $\mathrm{PGE}_{2}$ 의 생성 억제가 전사조절 인자인 NF- $\mathrm{kB}$ 와 상관성이 있는지를 조사한 결과, 핵 내로의 $\mathrm{NF}-\mathrm{kB}$ 이동이 ENIS 선처리에 의하여 억제되는 것으로 나타났 다. 이는 ENIS가 NF-kB의 활성 억제를 통하여 COX-2의 발현 및 $\mathrm{PGE}_{2}$ 의 생성을 효과적으로 억제함으로서 항염증 효능을 가진다는 것을 의미하는 결과이다. 하지만 ENIL의 경우에는 이상에서와 같은 이러한 변화들이 매우 약하게 나타나는 것으 로 조사되어 ENIS와 비교해서 항염증 효능이 낮은 것으로 나 타났다. 본 연구 결과는 협죽도의 항염증기전에 대한 생화학 적 해석 및 이를 활용한 향후 지속적인 연구를 위한 귀중한 자료가 될 것으로 생각된다. 


\section{감사의 글}

본 연구는 지식경제부·부산광역시 지원 지역혁신센터사업 동의대학교 블루바이오 소재 개발 및 실용화 지원 센터 (RIC08-06-07) 지원에 의하여 이루어진 결과입니다.

\section{References}

1. Achiwa, H., Y. Yatabe, T. Hida, T. Kuroishi, K. Kozaki, S. Nakamura, M. Ogawa, T. Sugiura, T. Mitsudomi, and T. Takahashi. 1999. Prognostic significance of elevated cyclooxygenase 2 expression in primary, resected lung adenocarcinomas. Clin. Cancer Res. 5, 1001-1005.

2. Bhandari, P., A. C. Bateman, R. L. Mehta, B. S. Stacey, P. Johnson, I. A. Cree, N. F. Di, and P. Patel. 2006. Prognostic significance of cyclooxygenase-2 (COX-2) expression in patients with surgically resectable adenocarcinoma of the oesophagus. BMC Cancer 6, 134, 2006.

3. Botting, R. M. 2006. Inhibitors of cyclooxygenases: mechanisms, selectivity and uses. J. Physiol. Pharmacol. 5, S113-124.

4. Brown, J. R. and R. N. DuBois. 2004. Cyclooxygenase as a target in lung cancer. Clin. Cancer Res. 10, S4266-4269.

5. Celec, P. 2004. Nuclear factor kappa B-molecular biomedicine: the next generation. Biomed Pharmacother. 58, 365-371.

6. Chen, G., E. Wood, S. H. Wang, and T. D. Warner. 1999. Expression of cyclooxygenase-2 in rat vascular smooth muscle cells is unrelated to nuclear factor-kappaB activation. Life Sci. 64, 1231-1242.

7. Ding, K., J. N. Fang, T. Dong, K. W. Tsim, and H. Wu. 2003. Characterization of a rhamnogalacturonan and a xyloglucan from nerium indicum and their activities on PC12 pheochromocytoma cells. J. Nat. Prod 66, 7-10.

8. Dong, Q. and J. N. Fang. 2001. Structural elucidation of a new arabinogalactan from the leaves of Nerium indicum Carbohydr. Res. 332, 109-114.

9. Eberhart, C. E., R. J. Coffey, A. Radhika, F. M. Giardiello, S. Ferrenbach, and R. N. DuBois. 1994. Up-regulation of cyclooxygenase 2 gene expression in human colorectal adenomas and adenocarcinomas. Gastroenterology 107, 11831188.

10. Funk, C. D. 2001. Prostaglandins and leukotrienes: advances in eicosanoid biology. Science 294, 1871-1875.

11. Giercksky, K. E. 2001. COX-2 inhibition and prevention of cancer. Best Pract. Res. Clin. Gastroenterol. 15, 821-833.

12. Harris, S. G., J. Padilla, L. Koumas, D. Ray, and R. P. Phipps. 2002. Prostaglandins as modulators of immunity. Trends Immund. 23, 144-150.

13. Hu, K., Q. Liu, S. Wang, and K. Ding. 2009. New oligosaccharides prepared by acid hydrolysis of the polysaccharides from Nerium indicum Mill and their anti-angiogenesis activities. Carbohydr. Res. 344, 198-203.

14. Ishikawa, A., H. Yamashita, M. Hiemori, E. Inagaki, M. Kimoto, M. Okamoto, H. Tsuji, A. N. Memon, A.
Mohammadio, and Y. Natori. 2007. Characterization of inhibitors of postprandial hyperglycemia from the leaves of Nerium indicum J. Nutr. Sci. Vitaminol. 53, 166-173.

15. Issac, T. T., H. Dokainish, and N. M. Lakkis. 2007. Role of inflammation in initiation and perpetuation of atrial fibrillation: a systematic review of the published data. J. Am Coll. Cardiol. 50, 2021-2028.

16. Janicke, H., P. M. Taylor, and C. E. Bryant. 2003. Lipopolysaccharide and interferon gamma activate nuclear factor kappa B and induce cyclooxygenase- 2 in equine vascular smooth muscle cells. Res. Vet. Sci. 75, 133-140.

17. Johnson, K. R., K. P. Becker, M. M. Facchinetti, Y. A. Hannun, and L. M. Obeid. 2005. PKC-dependent activation of sphingosine kinase 1 and translocation to the plasma membrane. Extracellular release of sphingosine-1-phosphate induced by phorbol 12-myristate 13-acetate (PMA). J. Biol. Chem 277, 35257-35262.

18. Kim, S. O., K. S. Chun, J. K. Kundu, and Y. J. Surh. 2004. Inhibitory effects of [6]-gingerol on PMA-induced COX-2 expression and activation of NF-kappaB and p38 MAPK in mouse skin. Biofactors 21, 27-31.

19. Koki, A., N. K. Khan, B. M. Woerner, A. J. Dannenberg, L. Olson, K. Seibert, D. Edwards, M. Hardy, P. Isakson, and J. L. Masferrer. 2002. Cyclooxygenase-2 in human pathological disease. Adv. Exp. Med Biol. 507, 177-184.

20. Komhoff, M., H. J. Grone, T. Klein, H. W. Seyberth, and R. M. Nusing. 1997. Localization of cyclooxygenase-1 and -2 in adult and fetal human kidney: implication for renal function. Am J. Physiol. 272, 460-468.

21. Lee, E., M. K. Choi, Y. J. Lee, J. L. Ku, K. H. Kim, J. S. Choi, and S. J. Lim. 2006. a-tocopheryl succinate, in contrast to a-tocopherol and a-tocopheryl acetate, inhibits prostaglandin E2 production in human lung epithelial cells. Carcinogenesis 27, 2308-2315.

22. Liden, J., I. Rafter, M. Truss, J. A. Gustafsson, and S. Okret. 2000. Glucocorticoid effects on NF-kappaB binding in the transcription of the ICAM-1 gene. Biochem Biophys. Res. Commun. 273, 1008-1014.

23. Mae, S. H., M. Sofia, R. L. Bolhuis, K. Nooter, R. G. Oostrum, W. Subagus, and G. G. Ibnu. 2008. Selectivity of compounds isolated from the leaves of Nerium indicum Mill. on various human cancer cell lines. Med J. Malaysia S63, A24-25.

24. Marwaha, V., Y. H. Chen, E. Helms, S. Arad, H. Inoue, E. Bord, R. Kishore, R. D. Sarkissian, B. A. Gilchrest, and D. A. Goukassian. 2005. T-oligo treatment decreases constitutive and UVB-induced COX-2 levels through p53- and NFkappaB-dependent repression of the COX-2 promoter. $J$. Biol. Chem 280, 32379-32388.

25. McCoy, J. M., J. R. Wicks, and L. P. Audoly. 2002. The role of prostaglandin E2 receptors in the pathogenesis of rheumatoid arthritis. J. Cin. Invest. 110, 651-658.

26. Meng, X. W., M. P. Heldebrant, and S. H. Kaufmann. 2002. Phorbol 12-myristate 13-acetate inhibits death receptor-mediated apoptosis in Jurkat cells by disrupting recruitment of Fas-associated polypeptide with death domain. J. Biol. Chem 277, 3776-3783. 
27. Murakami, M. and I. Kudo. 2004. Recent advances in molecular biology and physiology of the prostaglandin E2-biosynthetic pathway. Prog. Lipid Res. 43, 3-35.

28. Nakao, S., Y. Ogata, and H. Sugiya. 2009. Nicotine stimulates the expression of cyclooxygenase-2 mRNA via NFkappaB activation in human gingival fibroblasts. Arch Oral. Bid. 54, 251-257.

29. Parekh, D. B., W. Ziegler, and P. J. Parker. 2000. Multiple pathways control protein kinase $\mathrm{C}$ phosphorylation. $E M B O$ J. 19, 496-503.

30. Patel, T. N., M. H. Shishehbor, and D. L. Bhatt. 2007. A review of high-dose statin therapy: targeting cholesterol and inflammation in atherosclerosis. Eur. Heart J. 28, 664-672.

31. Pruett, S. B., R. Fan, and Q. Zheng. 2003. Characterization of glucocorticoid receptor translocation, cytoplasmic IkappaB, nuclear NFkappaB, and activation of NFkappaB in $\mathrm{T}$ lymphocytes exposed to stress-inducible concentrations of corticosterone in vivo. Int. Immunopharmacol. 3, 1-16.

32. Renò, F. and M. Cannas. 2005. Effect of prostaglandin E2 on PMA-induced macrophage differentiation. Prostaglandins Other Lipid Mediat. 75, 13-24.

33. Samad, T. A., K. A. Moore, A. Sapirstein, S. Billet, A. Allchorne, S. Poole, J. V. Bonventre, and C. J. Woolf. 2001. Interleukin-1 $\beta$-mediated induction of COX-2 in the CNS contributes to inflammatory pain hypersensitivity. Nature 410, 471-475.

34. Sandee, D., S. Sivanuntakorn, V. Vichai, J. Kramyu, and K. Kirtikara. 2009. Up-regulation of microsomal prostaglandin E synthase-1 in COX-1 and COX-2 knock-out mouse fibro- blast cell lines. Prostaglandins Other Lipid Mediat. 88, 111-116.

35. Simon, A. M., M. B. Manigrasso, and J. P. O'Connor. 2002. Cyclooxygenase-2 function is essential for bone fracture healing. J. Bone Miner. Res. 17, 963-976.

36. Thorén, S., R. Weinander, S. Saha, C. Jegerschöld, P. L. Pettersson, B. Samuelsson, H. Hebert, M. Hamberg, R. Morgenstern, and P. J. Jakobsson. 2003. Human microsomal prostaglandin E synthase-1: purification, functional characterization, and projection structure determination. J. Biol. Chem 278, 22199-22209.

37. Thun, M. J., S. J. Henley, and C. Patrono. 2002. Nonsteroidal anti-inflammatory drugs as anticancer agents: mechanistic, pharmacologic, and clinical issues. J. Natl. Cancer Inst. 94, 252-266.

38. Ulivi, V., R. Cancedda, and F. D. Cancedda. 2008. 15-deoxy-delta 12,14-prostaglandin J(2) inhibits the synthesis of the acute phase protein SIP24 in cartilage: Involvement of COX-2 in resolution of inflammation. J. Cell Physiol. 217, 433-441.

39. Wu, D., D. Mennerich, K. Arndt, K. Sugiyama, N. Ozaki, K. Schwarz, J. Wei, H. Wu, N. H. Bishopric, and H. Doods. 2009. Comparison of microsomal prostaglandin E synthase-1 deletion and COX-2 inhibition in acute cardiac ischemia in mice. Prostaglandins Other Lipid Mediat. 90, 21-25.

40. Yu, M. S., A. Y. Wong, K. F. So, J. N. Fang, W. H. Yuen, and R. C. Chang. 2007. New polysaccharide from Nerium indicum protects neurons via stress kinase signaling pathway. Brain Res. 1153, 221-230.

\section{초록 : NF- $\mathrm{kB}$ 활성 저해를 통한 협죽도 에탄올 추출물의 항염증 효능}

김태환 $^{1} \cdot$ 고석순 $^{3} \cdot$ 박 $^{\text {철 }} \cdot$ 박상은 $^{1} \cdot$ 홍상훈 $^{1} \cdot$ 김병우 $^{4,56} \cdot$ 최영현 24,6 *

(동의 대학교 한의과대학 ${ }^{1}$ 내과학교실, ${ }^{2}$ 생화학교실 및 한의학연구소, ${ }^{3}$ 가야여자중학교, 동의 대학교 ${ }^{4}$ 대학원 바이오물질제어학과, ${ }^{5}$ 자연과학대학 생명응용학과, ${ }^{6}$ 블루바이오소재 개발센터)

정상세포뿐 만 아니라 형질 전환된 세포의 증식조절에 중요한 역할을 하는 것으로 알려진 COX-2는 전사조절 인자인 NF-kB에 의해서 조절되며, 염증반응에 있어서 중요한 역할을 하는 PGE2의 생성에 관여하는 것으로 알려 져 있다. 본 연구에서는 U937 인체혈구세포에서 염증유발인자인 PMA에 의해서 유발되는 염증반응에 있어서 중 요한 역할을 하는 COX-2 및 COX-2의 산물인 PGE2와 COX-2의 발현에 영향을 미치는 전사조절인자인 NF-kB의 발현에 협죽도 잎 및 줄기의 에탄올 추출물인 ENIL 및 ENIS가 어떠한 영향을 미치는 지를 조사하였다. PMA가 처리된 U937 세포에서 COX-1의 발현에는 아무런 영향을 미치지 못하였지만 COX-2의 발현 증가가 유도되었고 이에 따른 PGE2의 생성이 증가되었다. PMA에 의해서 증가된 COX-2의 발현이 ENIS 선처리에 의하여 거의 완벽 하게 억제되었고 그에 따른 PGE2의 생성도 현저하게 감소되었다. ENIS에 의한 COX-2의 발현 및 PGE2의 생성 억제가 전사조절인자인 NF-kB와 상관성이 있는지를 조사한 결과, 핵 내로의 NF-kB 이동이 ENIS 선처리에 의하 여 억제되는 것으로 나타났다. 이는 ENIS가 NF-kB의 활성 억제를 통하여 COX-2의 발현 및 PGE2의 생성을 효과 적으로 억제함으로서 항염증 효능을 가진다는 것을 의미하는 결과이다. 하지만 ENIL의 경우에는 이상에서와 같 은 이러한 변화들이 매우 약하게 나타나는 것으로 조사되어 ENIS와 비교해서 항염증 효능이 낮은 것으로 나타났 다. 본 연구 결과는 협죽도의 항염증기전에 대한 생화학적 해석 및 이를 활용한 향후 지속적인 연구를 위한 귀중 한 자료가 될 것으로 생각된다. 